\title{
DETERMINAN PENGUNGKAPAN CORPORATE SOCIAL RESPONSIBILITY: STUDI EMPIRIS PADA PERUSAHAAN MANUFAKTUR YANG TERDAFTAR DI BURSA EFEK INDONESIA
}

\author{
Nanda Amelia Jauhari \\ Universitas ‘Aisyiyah Yogyakarta \\ Email: nandaameliajauhari13@gmail.com \\ Fajar Satriya Segarawasesa \\ Universitas 'Aisyiyah Yogyakarta \\ Email: fajarsatriyas@unisayogya.ac.id
}

\begin{abstract}
This study aims to analyze and provide empirical evidence on the effect of firm age, foreign ownership, board of commissioners, audit committee, and industry type on corporate social responsibility disclosure. The population in this study is manufacturing companies listed on the Indonesia Stock Exchange during 2017-2019, totalling 180 companies. The sampling technique used is the purposive sampling method with a total sample of 96 companies that met the criteria for the research samples. This study applies a quantitative approach with secondary data types. Data collection uses documentation techniques. Data analysis uses descriptive analysis and multiple regression analysis employed SPSS version 21 program. The results show that the company's age, the board of commissioners and the type of industry have a positive effect on the disclosure of corporate social responsibility, while foreign ownership and the audit committee do not affect the corporate social responsibility disclosure.
\end{abstract}

Keywords: Corporate Social Responsibility, Company Age, Foreign Ownership, Board of Commissioners, Audit Committee, Industry Type

\section{PENDAHULUAN}

Perusahaan merupakan bagian dari lingkungan dan masyarakat. Perusahaan yang berdiri di suatu wilayah secara otomatis akan memiliki tanggung jawab untuk memperhatikan dan menjaga lingkungan di sekitar untuk mencegah dampak negatif yang kemungkinan timbul selama proses industri berlangsung. Dalam menjalankan aktivitas perusahaan, sering kali ditemui kesenjangan antara pihak perusahaan dan masyarakat perihal isu sosial dan lingkungan. Hal ini dikarenakan masyarakat zaman sekarang sudah semakin sadar akan dampak aktivitas perusahaan terhadap lingkungannya.

Perkembangan ilmu pengetahuan dan teknologi yang ditandai dengan industri yang semakin maju berdampak pada semakin kompleksnya aktivitas operasional serta tanggung jawab sosial perusahaan (Purnaningsih, 2018). Kondisi tersebut menyebabkan perusahaan memiliki tuntutan yang lebih besar tidak hanya dalam hal ekonomi yaitu mencari keuntungan atau laba, tetapi juga terhadap kepentingan masyarakat sekitar (stakeholder). Pertanggungjawaban sosial terhadap para stakeholder ini biasa dikenal dengan istilah Corporate Social Responsibility (CSR). CSR merupakan program perusahaan yang memiliki tujuan untuk memberi tanggung jawab sebagai bentuk kepedulian dan kontribusi baik dalam bidang sosial maupun lingkungan kepada para stakeholder.

Di Indonesia, pengungkapan tanggung jawab sosial perusahaan telah diatur dalam Undang-Undang Nomor 40 Tahun 2007 tentang Perseroan Terbatas yang menyatakan 
Nanda Amelia Jauhari, Fajar Satriya Segarawasesa | Determinan Pengungkapan Corporate Social Responsibility (Studi Empiris pada Perusahaan Manufaktur yang Terdaftar di Bursa Efek Indonesia)

bahwa perseroan yang menjalankan kegiatan usahanya di bidang dan/atau berkaitan dengan sumber daya alam wajib melaksanakan tanggung jawab sosial dan lingkungan. Meski telah diatur dalam undang-undang, nyatanya nilai kualitas CSR di Indonesia masih terbilang rendah. Hal ini sesuai dengan hasil riset yang dilakukan oleh Centre for Governance, Institutions \& Organisations NUS Bussiness School terhadap 100 perusahaan di lima negara yaitu Indonesia, Thailand, Singapura, Malaysia, dan Filipina pada tahun 2018 yang mana diperoleh bahwa Indonesia merupakan negara dengan nilai CSR terendah dibandingan negara ASEAN lainnya yaitu sebesar 53,6\%. Rendahnya nilai kualitas CSR ini dapat dilihat dari masih banyaknya kasus CSR yang terjadi di Indonesia, salah satu contohnya yaitu kasus PT. Lapindo Brantas INC atau kasus lumpur Lapindo. Semburan lumpur panas disertai gas ini menenggelamkan area pemukiman, pertanian, dan industri di tiga kecamatan yaitu Kecamatan Porong, Kecamatan Tanggulangin, dan Kecamatan Jabon. Sebanyak empat desa di lahan seluas 400 hektare (ha) terdampak langsung dari semburan lumpur panas itu. Total korban disinyalir mencapai 45 ribu jiwa yang harus kehilangan pemukiman dan akhirnya memilih mengungsi ke wilayah lain. Tercatat selama 13 tahun menyembur, lumpur Lapindo telah menyedot dana APBN sebesar Rp11 triliun.

Penelitian ini merupakan penelitian pengembangan dari Saputri (2019) yang meneliti mengenai analisis faktor-faktor yang mempengaruhi pengungkapan CSR. Adapun perbedaan penelitian ini dengan penelitian sebelumnya yaitu mengganti variabel kepemilikan institusional dengan variabel kepemilikan asing (Sumilat dan Destriana, 2017) sesuai dengan saran peneliti sebelumnya. Kepemilikan asing dalam perusahaan merupakan pihak yang dianggap concern terhadap pengungkapan pertanggungjawaban sosial perusahaan, maka perusahaan dengan kepemilikan asing yang besar akan terdorong untuk melaporkan atau mengungkapkan informasinya secara sukarela dan luas. Kedua, menambahkan variabel tipe industri. Tipe industri membawa dampak operasi perusahaan terhadap lingkungan dan masyarakat. Perusahaan yang memiliki dampak yang besar terhadap lingkungan dan masyarakat akan mengungkapkan lebih banyak informasi sosial. Atas dasar perbedaan berbagai penelitian tersebut mendorong penulis menguji kembali faktor-faktor yang mempengaruhi pengungkapan CSR dengan judul "Determinan Pengungkapan Corporate Social Responsibility (Studi Empiris pada Perusahaan Manufaktur yang Terdaftar di Bursa Efek Indonesia)". Adapun variabel yang akan diuji kembali dalam penelitian ini yaitu umur perusahaan, kepemilikan asing, dewan komisaris, komite audit dan tipe industri yang dilakukan pada perusahaan manufaktur yang terdaftar di BEI.

\section{TINJAUAN PUSTAKA}

\section{Teori Agensi}

Teori agensi adalah dasar teori yang menjadi acuan dalam pelaksanaan praktik bisnis suatu perusahaan. Jensen dan Meckling (1976) menyatakan bahwa teori agensi merupakan sebuah kontrak yang terjadi antara manajer (agent) dengan pemilik perusahaan (principal). Para pemegang saham sebagai prinsipal akan memberikan wewenang penuh kepada manajemen sebagai agen. Manajemen disini akan bertanggungjawab secara moral untuk mengoptimalkan keuntungan para prinsipal. Manajemen sebagai pihak yang memiliki dan menyediakan informasi perusahaan wajib melaporkan laporan keuangan terhadap pemegang saham. Namun apabila dalam menyampaikan informasinya manajemen tidak bertindak secara transparan, maka hal tersebut akan menghambat pengambilan keputusan oleh prinsipal. Hal ini biasa disebut dengan konflik keagenan dimana manajemen memiliki lebih banyak informasi terkait perusahaan daripada pemegang saham (Nindiasari, 2021). Konflik keagenan juga dapat dikurangi dengan adanya penerapan mekanisme good corporate governance (GCG) sebagai mekanisme dalam hal pengendalian perusahaan. Penerapan GCG diharapkan dapat menciptakan monitoring kerja yang efektif, karena semua pihak yang berkepentingan dengan perusahaan akan melakukan usahanya secara baik sesuai 
Nanda Amelia Jauhari, Fajar Satriya Segarawasesa | Determinan Pengungkapan Corporate Social Responsibility (Studi Empiris pada Perusahaan Manufaktur yang Terdaftar di Bursa Efek Indonesia)

dengan hak dan kewajibannya sehingga dapat menurunkan biaya agensi (Wahyu \& Apriwenni, 2012).

\section{Teori Legitimasi}

Legitimasi merupakan keadaan psikologis keberpihakan orang dan kelompok orang yang sangat peka terhadap gejala lingkungan sekitarnya baik fisik maupun non fisik. Definisi tersebut mengisyaratkan bahwa legitimasi merupakan sistem pengelolaan perusahaan yang berorientasi pada keberpihakan terhadap masyarakat (society), pemerintah, individu dan kelompok masyarakat (Purnaningsih, 2018). Legitimasi merupakan faktor penting bagi perusahaan. Hal ini dikarenakan legitimasi dari masyarakat dapat menjadi salah satu faktor penentu perkembangan perusahaan. Teori legitimasi memfokuskan perusahaan terhadap interaksinya dengan masyarakat, sehingga sebuah organisasi mampu untuk menciptakan keselarasan antara nilai-nilai sosial yang melekat pada kegiatannya dengan norma-norma perilaku yang ada dalam sistem sosial masyarakat di mana organisasi adalah bagian dari sistem tersebut (Mudjiyanti \& Maulani, 2017).

\section{Corporate Social Responsibility (CSR)}

Menurut Undang-Undang Republik Indonesia Nomor 40 Tahun 2007 tentang Perseroan Terbatas, CSR atau pertanggungjawaban sosial adalah komitmen perseroan untuk berperan serta dalam pembangunan ekonomi berkelanjutan guna meningkatkan kualitas kehidupan dan lingkungan yang bermanfaat, baik bagi perseroan sendiri, komunitas setempat, maupun masyarakat pada umumnya. Sementara menurut UndangUndang Republik Indonesia Nomor 25 Tahun 2007 tentang Penanaman Modal, CSR adalah tanggung jawab yang melekat pada setiap perusahaan penanaman modal untuk tetap menciptakan hubungan yang serasi, seimbang, dan sesuai dengan lingkungan, nilai, norma, dan budaya masyarakat setempat. Menurut World Business Council for Sustainable Development (2000), CSR adalah komitmen berkesinambungan untuk berperilaku etis dan memberikan kontribusi bagi pembangunan ekonomi, kualitas kehidupan karyawan, dan masyarakat. Dari definisi-definisi tersebut maka dapat disimpulkan bahwa CSR merupakan kewajiban perusahaan, di mana perusahaan tidak mengumpulkan keuntungan untuk dirinya sendiri tetapi juga memperhatikan aspek sosial sebagai bentuk tanggung jawab terhadap lingkungan tempatnya beroperasi.

Pengungkapan tanggung jawab sosial perusahaan adalah proses komunikasi antara perusahaan dengan pihak-pihak lain yang berkepentingan atau tidak atas kegiatan operasional perusahaan serta efek yang ditimbulkan dan bagaimana penanggulangan yang sudah dilakukan oleh perusahaan untuk meminimalkan dampak tersebut (Oktariani, 2013). Tujuan pengungkapan adalah menyajikan informasi yang dipandang perlu untuk mencapai tujuan pelaporan keuangan dan melayani kebutuhan berbagai pihak yang mempunyai kepentingan berbeda-beda (Soewardjono, 2015). Keberhasilan pelaksanaan ini perlu diungkapkan perusahaan sebagai salah satu upaya untuk meningkatkan citra perusahaan di masyarakat, khususnya investor (Sudana \& Arlindania, 2011).

\section{Umur Perusahaan}

Umur perusahaan adalah lama waktu perusahaan didirikan hingga berkembang dalam menjalankan bisnisnya. Umur perusahaan umumnya dapat mencerminkan banyaknya pengalaman dan pengetahuan untuk mengatasi masalah-masalah yang dihadapi oleh perusahaan. Umur perusahaan menunjukkan kredibilitas maupun reputasi perusahaan di mata masyarakat (Sanditoso \& Chandra, 2012). Pada kondisi normal, perusahaan yang telah lama berdiri akan mempunyai pengelolaan informasi akuntansi yang lebih daripada perusahaan yang baru berdiri sehingga perusahaan akan memiliki kinerja yang baik dan tingkat kepercayaan masyarakat terhadap perusahaan tersebut juga tinggi. Oleh karena itu, perusahaan yang telah lama berdiri tentu akan selalu menjaga stabilitas dan citra perusahaan tersebut. 
Nanda Amelia Jauhari, Fajar Satriya Segarawasesa | Determinan Pengungkapan Corporate Social Responsibility (Studi Empiris pada Perusahaan Manufaktur yang Terdaftar di Bursa Efek Indonesia)

\section{Kepemilikan Asing}

Kepemilikan asing adalah jumlah saham yang dimiliki oleh pihak asing (luar negeri) baik individu maupun lembaga terhadap saham di perusahaan Indonesia. Pemilik saham asing berbagi budaya dan nilai yang berbeda dengan anggota yang ada. Kepemilikan asing juga memiliki beragam pengalaman dan keahlian yang bekerja di lingkungan berbeda yang mengarahkan mereka untuk memantau dan memberikan saran kepada manajemen tentang cara meningkatkan nilai dan reputasi organisasi. Dengan keberadaan investor asing dalam perusahan domestik, pengawasan terhadap performa perusahaan akan lebih baik, dan dengan tenaga-tenaga ahli yang kontrak oleh para investor asing akan meningkatkan firm value sehingga dapat dilirik oleh para calon investor lainnya (Taduga \& Noval, 2019).

\section{Dewan Komisaris}

Dewan komisaris sebagai organ perusahaan bertugas dan bertanggungjawab secara kolektif untuk melakukan pengawasan dan memberikan nasihat kepada direksi serta memastikan bahwa perusahaan melaksanakan GCG (KNKG, 2006). Terkait pengawasan di dalam suatu perusahaan, dewan komisaris mewakili mekanisme internal utama untuk melaksanakan fungsi pengawasan dari prinsipal dan mengontrol perilaku oportunis manajemen (Sukandar \& Rahardja, 2014). Ukuran dewan komisaris adalah seluruh jumlah dewan komisaris yang dimiliki oleh suatu perusahaan. Dikaitkan dengan pengungkapan tanggung jawab sosial perusahaan, maka tekanan terhadap manajemen juga akan semakin besar untuk mengungkapkannya (Arfansyah, 2018).

Dalam POJK Nomor 33/POJK.04/2014 tentang Direksi dan Dewan Komisaris Emiten atau Perusahaan Publik pada pasal 21 ayat 2, komisaris independen wajib memenuhi persyaratan sebagai berikut.

a. Bukan merupakan orang yang bekerja atau mempunyai wewenang dan tanggung jawab untuk merencanakan, memimpin, mengendalikan, atau mengawasi kegiatan emiten atau perusahaan publik tersebut dalam waktu 6 (enam) bulan terakhir, kecuali untuk pengangkatan kembali sebagai komisaris independen emiten atau perusahaan publik pada periode berikutnya.

b. Tidak mempunyai saham baik langsung maupun tidak langsung pada emiten atau perusahaan publik tersebut.

c. Tidak mempunyai hubungan afiliasi dengan emiten atau perusahaan publik, anggota dewan komisaris, anggota direksi, atau pemegang saham utama emiten atau perusahaan publik tersebut.

d. Tidak mempunyai hubungan usaha baik langsung maupun tidak langsung yang berkaitan dengan kegiatan usaha emiten atau perusahaan publik tersebut.

Menurut KNKG (2006) agar pelaksanaan tugas dewan komisaris dapat berjalan secara efektif, perlu dipenuhi prinsip-prinsip berikut.

a. Komposisi dewan komisaris harus memungkinkan pengambilan keputusan secara efektif, tepat dan cepat, serta dapat bertindak independen.

b. Anggota dewan komisaris harus profesional, yaitu berintegritas dan memiliki kemampuan sehingga dapat menjalankan fungsinya dengan baik termasuk memastikan bahwa direksi telah memperhatikan kepentingan semua pemangku kepentingan.

c. Fungsi pengawasan dan pemberian nasihat dewan komisaris tindakan pencegahan, perbaikan, sampai kepada pemberhentian sementara.

\section{Komite Audit}

POJK No. 55/POJK.04/2015 tentang Pembentukan dan Pedoman Pelaksanaan Kerja Komite Audit menyatakan bahwa komite audit adalah komite yang dibentuk oleh dan bertanggung jawab kepada dewan komisaris dalam membantu melaksanakan tugas dan fungsi dewan komisaris. Natalylova (2013) menyatakan bahwa komite audit harus terdiri dari individu-individu yang mandiri dan tidak terlibat dengan tugas sehari-hari dari 
Nanda Amelia Jauhari, Fajar Satriya Segarawasesa | Determinan Pengungkapan Corporate Social Responsibility (Studi Empiris pada Perusahaan Manufaktur yang Terdaftar di Bursa Efek Indonesia)

manajemen yang mengelola perusahaan, dan yang memiliki pengalaman untuk melaksanakan fungsi pengawasan secara efektif.

Keberadaan komite audit dalam perusahaan di Indonesia merupakan suatu kewajiban. Hal ini sesuai dalam Pedoman Umum Good Corporate Governance (GCG) yang dikeluarkan Komite Nasional Kebijakan Governance (KNKG) 2006 yang menyatakan bahwa bagi perusahaan yang sahamnya tercatat di bursa efek, perusahaan negara, perusahaan daerah, perusahaan yang menghimpun dan mengelola dana masyarakat, perusahaan yang produk dan jasanya digunakan oleh masyarakat luas, serta perusahaan yang memiliki dampak luas terhadap kelestarian lingkungan, sekurang-kurangnya harus membentuk komite audit.

\section{Tipe Industri}

Tipe industri adalah karakteristik yang dimiliki oleh perusahaan yang berkaitan dengan bidang usaha, risiko usaha, karyawan yang dimiliki, dan lingkungan perusahaan. Tipe industri mencerminkan kegiatan operasi perusahaan dan dampaknya terhadap lingungan dan sosial. Tipe industri diklasifikasikan ke dalam dua golongan yaitu industri high profile dan low profile. Nurhayati dkk. (2006) menyatakan bahwa BEI juga mengklasifikasikan industri yang terdiri dari sembilan industri dalam pengkodean lowhigh. Tujuh industri yaitu agrikultur, tambang, industri dasar dan bahan kimia, industri lain-lain, industri barang konsumsi, properti dan real estate, infrastruktur, utilitas dan transportasi diklasifikasikan dengan high profile industry sedangkan dua lainnya, keuangan dan perdagangan, jasa dan investasi diklasifikasikan dengan low profile industry. Ismaningtyas dkk. (2020) juga menyatakan bahwa industri yang mempunyai tingkat sensitivitas terhadap kerusakan lingkungan yang tinggi termasuk ke dalam tipe industri high profile, contohnya adalah perusahaan kimia, perminyakan, pertambangan, otomotif, penerbangan, tembakau, rokok, food and beverages, dan pariwisata. Sementara industri yang mempunyai tingkat sensitivitas terhadap kerusakan lingkungan yang rendah termasuk ke dalam tipe industri low profile, contohnya adalah perusahaan real estate, keuangan, perbankan, properti, tekstil, dan retailer. Perusahaan dengan tipe industri high profile akan lebih banyak membawa dampak negatif terhadap lingkungan dikarenakan oleh proses industrinya. Keadaan tersebut membuat perusahaan high profile menjadi lebih mendapatkan sorotan oleh masyarakat luas mengenai aktivitas perusahaannya, sedangkan industri low profile adalah kebalikannya. Perusahaan low profile memiliki tingkat consumer visibility, tingkat risiko politik, dan tingkat kompetisi yang rendah, sehingga tidak terlalu mendapat sorotan dari masyarakat luas mengenai aktivitas perusahaannya meskipun dalam melakukan aktivitasnya tersebut perusahaan melakukan kesalahan atau kegagalan pada proses maupun hasil produksinya (Adawiyah, 2013).

\section{Penelitian yang Relevan}

Beberapa peneliti terdahulu telah menemukan bukti empiris tentang faktor-faktor yang memengaruhi pengungkapan CSR dengan hasil penelitian yang beragam. Penelitian yang dilakukan oleh Wati (2018) dengan menggunakan teori stakeholder menunjukkan hasil bahwa GCG, profitabilitas perusahaan, dan ukuran perusahaan berpengaruh positif terhadap pengungkapan CSR baik secara total maupun terhadap dimensinya yaitu pengungkapan ekonomi, lingkungan, dan sosial. Sementara pertumbuhan perusahaan dan usia perusahaan bukan merupakan faktor penentu pengungkapan CSR di perusahaan manufaktur Indonesia.

Penelitian yang dilakukan oleh Saputri (2019) dengan menggunakan teori stakeholder dan teori keagenan menunjukkan hasil bahwa kepemilikan institusional, profitabilitas, leverage, dan komite audit tidak berpengaruh terhadap pengungkapan CSR. Sementara umur perusahaan, ukuran perusahaan, dan dewan komisaris berpengaruh positif terhadap pengungkapan CSR.

Penelitian yang dilakukan oleh Ismaningtyas dkk. (2020) dengan menggunakan teori stakeholder menunjukkan hasil bahwa profitabilitas, likuiditas, dan ukuran perusahaan berpengaruh positif terhadap CSR. Sementara leverage, kepemilikan saham publik, dan 
Nanda Amelia Jauhari, Fajar Satriya Segarawasesa | Determinan Pengungkapan Corporate Social Responsibility (Studi Empiris pada Perusahaan Manufaktur yang Terdaftar di Bursa Efek Indonesia)

tipe industri tidak berpengaruh terhadap CSR. Secara bersama-sama profitabilitas, likuiditas, leverage, ukuran perusahaan, kepemilikan saham publik, dan tipe industri berpengaruh terhadap CSR.

\section{Rerangka Pemikiran}

Variabel dalam penelitian ini menggunakan dua jenis variabel yaitu variabel dependen dan variabel independen. Variabel dependen adalah pengungkapan CSR sedangkan variabel independen adalah umur perusahaan, kepemilikan asing, dewan komisaris, komite audit, dan tipe industri. Gambar 1 menunjukkan rerangka pemikiran dalam penelitian ini.

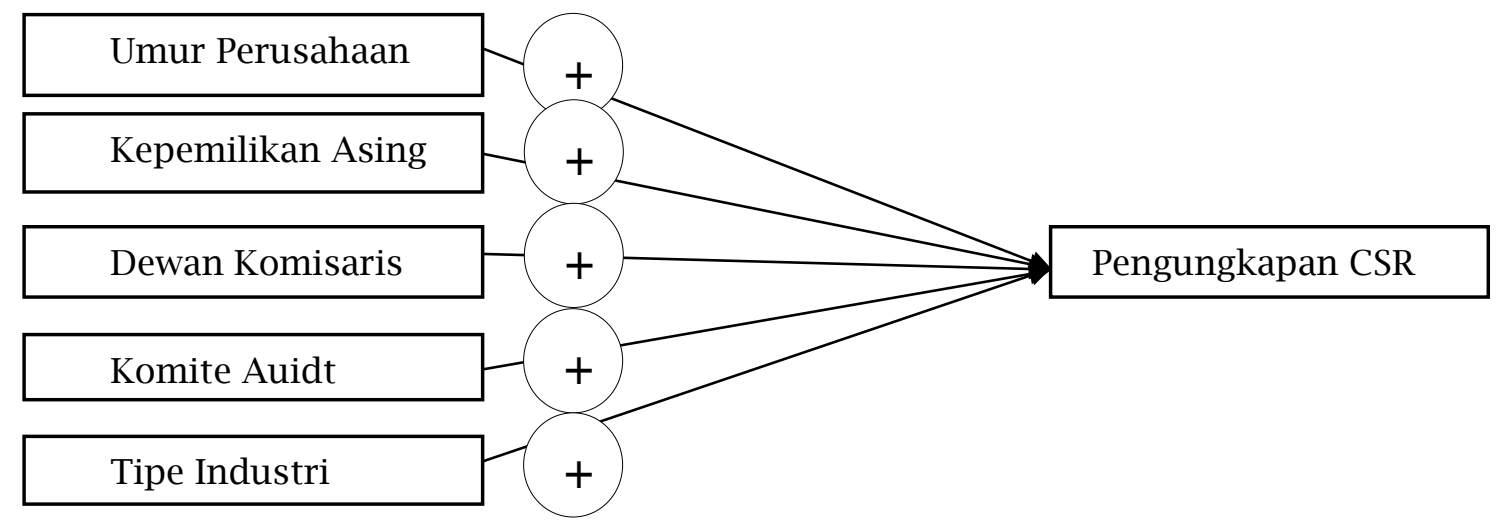

Gambar 1. Rerangka Pemikiran

\section{Pengembangan Hipotesis}

\section{Pengaruh Umur Perusahaan terhadap Pengungkapan CSR}

Umur perusahaan adalah lama waktu perusahaan didirikan hingga berkembang dalam menjalankan operasinya. Umur perusahaan yang lama diyakini lebih dipercaya oleh masyarakat dari segi peningkatan laba dan citra baik yang telah ditunjukkan oleh perusahaan sejak perusahaan tersebut berdiri (Vivian dkk., 2020). Perusahaan yang telah lama berdiri disertai dengan jam kerja yang tinggi akan lebih banyak mengumpulkan, memproses, dan menghasilkan informasi tentang perusahaan (Arjanggie \& Zulaikha, 2015). Berdasarkan teori legitimasi, legitimasi organisasi dapat dilihat sebagai sesuatu yang diberikan masyarakat kepada perusahaan dan sesuatu yang sangat dibutuhkan oleh perusahaan dari masyarakat itu sendiri. Perusahaan yang memiliki umur yang panjang merupakan perusahaan yang dapat bertahan cukup lama dalam kehidupan bisnisnya, keberlangsungan hidup perusahaan ini terus berlanjut karena adanya sebuah pengakuan dari masyarakat yaitu legitimasi (Ciriyani \& Putra, 2016). Oleh karena itu, apabila perusahaan tersebut semakin lama bertahan, maka sebagai bentuk tanggung jawabnya kepada masyarakat, perusahaan tersebut akan semakin banyak mengungkapkan informasi lingkungannya pada laporan tahunan yang mereka terbitkan. Dengan demikian diharapkan masyarakat dapat terus menerima keberadaan perusahaan dan memberikan legitimasi mereka, sehingga keberlangsungan perusahaan dapat terus berlanjut.

H1: Umur perusahaan berpengaruh positif terhadap pengungkapan CSR.

\section{Pengaruh Kepemilikan Asing terhadap Pengungkapan CSR}

Kepemilikan asing adalah jumlah saham yang dimiliki oleh pihak asing (luar negeri) baik individu maupun lembaga terhadap saham di perusahaan Indonesia. Dengan adanya saham asing di perusahaan, maka akan dapat mempengaruhi kelengkapan pengungkapan tanggung jawab sosial oleh perusahaan. Hal ini dikarenakan semakin banyak pihak yang membutuhkan informasi tentang perusahaan untuk melakukan investasi, maka semakin banyak pula tuntutan akan informasi untuk diungkapkan, untuk itu diperlukan pengungkapan tanggung jawab sosial perusahaaan yang lebih luas. Dalam teori agensi dijelaskan bahwa keahlian dalam sistem informasi dan tanggung 
Nanda Amelia Jauhari, Fajar Satriya Segarawasesa | Determinan Pengungkapan Corporate Social Responsibility (Studi Empiris pada Perusahaan Manufaktur yang Terdaftar di Bursa Efek Indonesia)

jawab sosial yang lebih tinggi mengindikasikan kepemilikan asing akan mengurangi agency cost dikarenakan pemilik asing sebagai prinsipal bisa lebih bijaksana dalam menyatukan tujuannya dengan agen (manajer) dalam setiap aktivitas perusahaan.

H2: Kepemilikan asing berpengaruh positif terhadap CSR.

\section{Pengaruh Dewan Komisaris terhadap pengungkapan CSR}

Dewan komisaris merupakan inti dari GCG yang ditugaskan untuk menjamin pelaksanaan strategi perusahaan, mengawasi manajemen dalam mengelola perusahaan, dan mewajibkan terlaksananya akuntabilitas (Alang, 2018). Dalam teori agensi, dewan komisaris dianggap sebagai mekanisme pengendalian intern tertinggi yang bertanggung jawab untuk memonitor tindakan manajemen puncak. Dengan kekuasaan dewan komisaris yang luas dalam mengawasi dan mengendalikan manajemen perusahaan agar pengelolaan perusahaan semakin efektif, maka dengan kekuasaan dewan komisaris tersebut dapat digunakan untuk memberikan pengaruh yang besar dalam pelaksanaan CSR. Sembiring (2006) menyatakan bahwa semakin besar jumlah anggota dewan komisasris, maka semakin mudah untuk mengendalikan direksi dan pengawasan yang dilakukan akan semakin efektif.

H3: Dewan komisaris berpengaruh positif terhadap pengungkapan CSR.

\section{Pengaruh Komite Audit terhadap pengungkapan CSR}

Komite audit merupakan salah satu mekanisme pengendalian dalam perusahaan yang sangat penting dalam meningkatkan transparansi perusahaan dan mendorong manajemen agar mengungkapkan lebih banyak informasi dalam perusahaan (Budiman, 2015). Adanya anggota independen dalam komite audit dapat menjadi alat yang efektif untuk melakukan mekanisme pengawasan sehingga dapat mengurangi biaya agensi, meningkatkan pengendalian internal, dan akan meningkatkan kualitas pengungkapan informasi perusahaan (Said dkk., 2009). Teori agensi memprediksikan bahwa pembentukan komite audit merupakan cara untuk menyelesaikan agency problems. Hal ini dikarenakan salah satu tugas komite audit adalah untuk mereview pengendalian internal perusahaan, memastikan kualitas laporan keuangan, dan meningkatkan efektivitas fungsi audit. Komite audit bertanggung jawab secara profesional dan independen tanpa campur tangan dari pihak manapun yang tidak sesuai dengan perundang-undangan. Keberadaan komite audit mendorong terciptanya praktik yang sehat dalam pelaporan keuangan, manajemen risiko, pengendalian internal, dan etika bisnis yang baik (Segarawasesa, 2021). Selain itu keberadaan komite audit mendukung prinsip pertanggungjawaban dalam penerapan GCG yang mengharuskan perusahaan untuk memberikan informasi yang lebih baik kepada stakeholder (Diyanti, 2013). Maka semakin banyak anggota komite audit yang dimiliki, kontrol terhadap kinerja sosial perusahaan akan semakin besar sehingga memperluas pengungkapan tanggung jawab sosialnya (Suryono \& Prastiwi, 2011).

H4: Komite audit berpengaruh positif terhadap pengungkapan CSR.

\section{Pengaruh Tipe Industri terhadap pengungkapan CSR}

Tipe industri mencerminkan kegiatan operasi perusahaan dan dampaknya terhadap lingkungan dan sosial. Tipe industri dibedakan menjadi dua jenis yaitu, industri high profile dan industri low profile. Menurut Ismaningtyas dkk. (2020), industri high profile akan lebih banyak melakukan pengungkapan tanggung jawab sosial perusahaan dibandingkan dengan industri low profile. Hal tersebut dikarenakan perusahaan yang bertipe high profile dalam melakukan aktivitasnya banyak memodifikasi lingkungan, dan menimbulkan dampak sosial yang negatif terhadap masyarakat (Pratiwi \& Ismawati, 2019). Teori legitimasi menjadi dasar dalam menjelaskan hubungan jenis industri high profile versus low profile dengan pengungkapan CSR perusahaan. Teori legitimasi berhubungan erat dengan norma-norma yang ada di masyarakat. Teori legitimasi melandasi adanya kontrak sosial antara perusahaan dengan masyarakat yang berdampak saling menguntungkan antara kedua belah pihak, salah satunya dengan melalui kegiatan CSR (Widiastuti dkk., 2018). Aktivitas operasi perusahaan yang 
Nanda Amelia Jauhari, Fajar Satriya Segarawasesa | Determinan Pengungkapan Corporate Social Responsibility (Studi Empiris pada Perusahaan Manufaktur yang Terdaftar di Bursa Efek Indonesia)

membawa dampak terhadap lingkungan dan sosial masyarakat, perlu melakukan kegiatan CSR sebagai upaya meminimalkan konflik serta untuk mendapatkan legitimasi dari masyarakat.

H5: Tipe industri berpengaruh positif terhadap pengungkapan CSR.

\section{METODE PENELITIAN}

\section{Jenis Penelitian dan Variabel Penelitian}

Jenis penelitian yang digunakan dalam penelitian ini yaitu penelitian kuantitatif yang menjelaskan tentang pengaruh umur perusahaan, kepemilikan asing, dewan komisaris, komite audit, dan tipe industri terhadap pengungkapan CSR. Variabel dependen adalah variabel yang dipengaruhi oleh variabel bebas. Variabel dependen dalam penelitian ini adalah pengungkapan Corporate Social Responsibility (CSR). Variabel independen adalah variabel bebas yang mempengaruhi variabel terikat. Variabel independen dalam penelitian ini adalah umur perusahaan, kepemilikan asing, dewan komisaris, komite audit, dan tipe industri.

\section{Definisi Operasional dan Pengukuran Variabel}

\section{Corporate Social Responsibility (CSR)}

Variabel dependen yang akan diteliti dalam penelitian ini adalah CSR atau pengungkapan tanggung jawab sosial. Pengukuran pengungkapan tanggung jawab sosial perusahaan yaitu dengan menggunakan metode checklist. Pengukuran pengungkapan CSR diukur dengan porsi CSR berdasarkan Indikator Global Reporting Initiative (GRI) 4 . Terdapat 3 komponen utama kinerja, yaitu ekonomi, lingkungan dan sosial. Adapun komponen kinerja sosial terbagi lagi dalam sub-indikator keternagakerjaan dan kenyamanan kerja, yaitu, masyarakat, tanggung jawab atas produk dan hak asasi manusia. GRI 4 terdiri dari 91 item. Metode pengukuran yang digunakan dalam penelitian ini berdasarkan pengukuran yang telah dilakukan oleh Saputri (2019).

Adapun rumus perhitungan CSR dalam penelitian ini adalah sebagai berikut: CSRIj merupakan indeks luas pengungkapan CSR perusahaan. CSRD $=\frac{\sum x i j}{n j}$ dengan $\sum x i$ merupakan jumlah item yang diungkapkan perusahaan yang dinotasikan dengan angka 1 jika item i diungkapkan, dan angka 0 jika item i tidak diungkapkan, dan $n_{\mathrm{i}}$ merupakan total item yang berjumlah 91.

\section{Umur Perusahaan}

Umur perusahaan adalah berapa lamanya perusahaan didirikan dan beroperasi. Pengukuran umur perusahaan yang digunakan dalam penelitian ini bercermin dari penelitian yang dilakukan oleh Istiandra (2018), yaitu umur perusahaan dihitung dari awal perusahaan beroperasi hingga perusahaan tersebut dapat mempertahankan eksistensinya dalam dunia bisnis. Dalam penelitian ini, umur perusahaan merupakan tahun perusahaan didirikan hingga menjadi sampel penelitian.

\section{Kepemilikan Asing}

Kepemilikan asing adalah jumlah saham yang dimiliki oleh pihak asing (luar negeri) baik individu maupun lembaga terhadap saham di perusahaan Indonesia. Pengukuran kepemilikan asing yang digunakan dalam penelitian ini bercermin dari penelitian yang dilakukan oleh Sumilat dan Destriana (2017), yaitu variabel dummy dengan nilai 1 jika ada kepemilikan asing, dan nilai 0 jika tidak ada kepemilikan asing.

\section{Dewan Komisaris}

Dewan komisaris merupakan organ perusahaan yang fungsi utamanya memberi perhatian serta bertanggung jawab atas pengelolaan perusahaan dalam rangka mencapai maksud dan tujuan perusahaan. Pengukuran dewan komisaris yang digunakan dalam penelitian ini bercermin dari penelitian yang dilakukan oleh Sukasih dan Sugiyanto (2017). Dewan komisaris diukur dari jumlah dewan komisaris dalam perusahaan. 
Nanda Amelia Jauhari, Fajar Satriya Segarawasesa | Determinan Pengungkapan Corporate Social Responsibility (Studi Empiris pada Perusahaan Manufaktur yang Terdaftar di Bursa Efek Indonesia)

\section{Komite Audit}

Komite audit merupakan salah satu mekanisme pengendalian dalam perusahaan yang sangat penting dalam meningkatkan transparansi perusahaan dan mendorong manajemen agar mengungkapkan lebih banyak informasi dalam perusahaan (Budiman, 2015). Pengukuran komite audit yang digunakan dalam penelitian ini bercermin dari penelitian yang dilakukan oleh Nurfadilah dan Sagara (2015), yaitu komite audit diukur dari jumlah komite audit dalam perusahaan.

\section{Tipe Industri}

Tipe industri mencerminkan kegiatan operasi perusahaan dan dampaknya terhadap lingungan dan sosial. Tipe industri dibedakan menjadi dua jenis yaitu, industri high profile dan industri low profile. Pengukuran tipe industri yang digunakan dalam penelitian ini bercermin dari penelitian yang dilakukan oleh Ismaningtyas dkk. (2020), yaitu variabel dummy, yang memberikan nilai 1 untuk tipe industri high profile, seperti perusahaan kimia, perminyakan, pertambangan, otomotif, penerbangan, tembakau, rokok, food and beverages dan pariwisata, dan nilai 0 untuk tipe industri low profile, seperti perusahaan real estate, keuangan, perbankan, properti, tekstil dan retailer.

\section{Jenis dan Sumber Data}

Penelitian ini menggunakan jenis data sekunder. Data dalam penelitian ini diperoleh melalui Annual Report dan Sustainability Report perusahaan-perusahaan manufaktur yang terdaftar di Bursa Efek Indonesia (BEI).

\section{Populasi dan Sampel}

Populasi dalam penelitian ini adalah seluruh perusahaan manufaktur yang terdaftar pada Bursa Efek Indonesia (BEI) periode 2017-2019. Dalam penelitian ini, teknik pengambilan sampel yang digunakan adalah purposive sampling, yaitu sampel yang diambil berdasarkan kriter-kriteria tertentu. Adapun jumlah populasi dalam penelitian ini yaitu sebanyak 180 perusahaan dengan perusahaan yang dijadikan sampel yaitu sebanyak 96 perusahaan.

\section{Teknik Pengumpulan Data}

Pengumpulan data dalam penelitian ini menggunakan metode dokumentasi yaitu dengan mengumpulkan dan mempelajari dokumen dan data yang diperlukan. Data yang dimaksud dalam penelitian ini adalah annual report dan sustainability report. Laporanlaporan tersebut diperoleh melalui www.idx.co.id yang merupakan situs resmi Bursa Efek Indonesia (BEI).

\section{Teknik Analisis Data}

Analisis data yang digunakan dalam penelitian ini yaitu menggunakan bantuan software komputer dengan program SPSS (Statistical Package for Social Science). Alat analisis yang digunakan dalam penelitian ini adalah analisis deskriptif dan analisis regresi linier berganda.

\section{Statistik Deskriptif}

Analisis statistik deskriptif dapat memberikan informasi deskriptif dari perhitungan nilai maksimum, nilai minimum, standar deviasi, dan nilai rata-rata (mean). Analisis ini bertujuan untuk memberikan gambaran mengenai perilaku dan distribusi suatu data sampel.

\section{Analisis Regresi Linier Berganda}

Analisis data dalam penelitian ini dilakukan dengan menggunakan model analisis regresi linier berganda pada persamaan (1).

$\mathrm{Y}=\alpha+\beta_{1} \mathrm{UP}+\beta_{2} \mathrm{KA}+\beta_{3} \mathrm{DEKOM}+\beta_{4} \mathrm{KOMDIT}+\beta_{5} \mathrm{TI}+\varepsilon$

Dimana CSRD merupakan corporate social responsibility disclosure; $\alpha$ merupakan konstanta; $\beta_{1}$ sampai $\beta_{5}$ merupakan koefisien regresi; UP merupakan umur perusahaan; 
Nanda Amelia Jauhari, Fajar Satriya Segarawasesa | Determinan Pengungkapan Corporate Social Responsibility (Studi Empiris pada Perusahaan Manufaktur yang Terdaftar di Bursa Efek Indonesia)

KA merupakan kepemilikan asing; DEKOM merupakan dewan komisaris; KOMDIT merupakan komite audit; TI merupakan tipe industri; dan $\varepsilon$ merupakan standar eror.

\section{HASIL DAN PEMBAHASAN}

\section{Statistik Deskriptif}

Penelitian ini menggunakan variabel independen yang terbagi menjadi data kontinu dan kategorikal. Statistik deskriptif varibel kontinu dijelaskan dalam Tabel 1.

Tabel 1. Hasil Analisis Statistik Deskriptif Varibel Kontinu

\begin{tabular}{lccccc}
\hline & $\mathrm{N}$ & Minimun & Maximum & Mean & Std. Deviation \\
\hline Umur Perusahaan & 288 & 12 & 90 & 43,46 & 15,247 \\
Dewan Komisaris & 288 & 2 & 11 & 4,07 & 1,800 \\
Komite Audit & 288 & 2 & 5 & 3,03 & 0,386 \\
CSR & 288 & 0,1 & 69 & 0,1539 & 0,10764 \\
\hline
\end{tabular}

Sumber: Data diolah, 2021

Dari hasil analisis pada Tabel 1 dapat diketahui bahwa untuk variabel umur perusahaan yang diukur menggunakan lamanya umur perusahaan berdiri hingga menjadi tahun sampel, diperoleh bahwa perusahaan dengan umur terendah yaitu PT. Indofood CBP Sukses Makmur Tbk yaitu 11 tahun, sedangkan untuk perusahaaan dengan umur terlama adalah PT. Sepatu Bata Tbk yaitu 90 tahun. Nilai rata-rata berjumlah sebesar 43,46 yang berarti bahwa perusahaan manufaktur di Indonesia ratarata memiliki umur perusahaan selama 43 tahun.

Untuk variabel dewan komisaris yang diukur menggunakan jumlah dewan komisaris, diperoleh bahwa nilai terendah dewan komisaris yaitu sebesar 2 yang dimiliki oleh PT. Ekadharma International Tbk, PT. Mark Dynamics Indonesia Tbk, PT. Betonjaya Manunggal Tbk, PT. Impack Pratama Industri Tbk, PT. Indo Komoditi Korpora Tbk, PT. Ateliers Mecaniques D Indonesie Tbk, PT. Buana Artha Anugerah Tbk, PT. Nusantara Inti Corpora Tbk, dan PT. Chitose Internasional Tbk. Nilai rata-rata berjumlah sebesar 4,07 atau 4 orang yang berarti bahwa rata-rata perusahaan manufaktur di Indonesia memiliki dewan komisaris sejumlah 4 orang atau melebihi jumlah yang diatur dalam POJK Nomor 33/POJK.04/2014 pasal 20 ayat 1 tentang Keanggotaan Dewan Direksi dan Dewan Komisaris yaitu dewan komisaris paling kurang terdiri dari 2 orang anggota dewan komisaris.

Untuk variabel komite audit yang diukur menggunakan jumlah komite audit diperoleh bahwa nilai terendah dewan komisaris yaitu sebesar 2 yang dimiliki oleh PT. Merck Tbk. Nilai rata-rata berjumlah sebesar 3,03 atau 3 orang yang berarti bahwa ratarata perusahaan manufaktur di Indonesia memiliki komite audit sejumlah 3 orang yang mana telah sesuai dengan aturan pemerintah yang diisyaratkan dalam POJK No. 55/POJK.04/2015 tentang Pembentukan dan Pedoman Pelaksanaan Kerja Komite Audit pasal 4 yang menyatakan bahwa komite audit paling sedikit terdiri dari 3 orang anggota yang berasal dari komisaris independen dan pihak dari luar emiten atau perusahaan publik.

Untuk variabel CSR yang diukur menggunakan indeks GRI 4, diperoleh bahwa nilai terendah CSR yaitu sebesar 0,1 yang dimiliki oleh PT. Siantar Top Tbk. Nilai rata-rata berjumlah sebesar 0,1539 yang berarti bahwa nilai rata-rata CSR dari seluruh sampel penelitian adalah 0,1539.

Tabel 2. Hasil Rata-Rata Varibel Kontinu

\begin{tabular}{lccc}
\hline & 2017 & 2018 & 2019 \\
\hline Umur Perusahaan & 43 & 43 & 43 \\
Dewan Komisaris & 4 & 4 & 4 \\
Komite Audit & 3 & 3 & 3 \\
\hline
\end{tabular}

Sumber: Data diolah, 2021 
Nanda Amelia Jauhari, Fajar Satriya Segarawasesa | Determinan Pengungkapan Corporate Social Responsibility (Studi Empiris pada Perusahaan Manufaktur yang Terdaftar di Bursa Efek Indonesia)

Hasil analisis statistik deskriptif variabel kategorikal dijelaskan dalam Tabel 3.

Tabel 3. Hasil Analisis Statistik Deskriptif Varibel Kategorikal

\begin{tabular}{llc}
\hline & \multicolumn{1}{c}{ Pengukuran } & Persentase \\
\hline Kepemilikan Asing & $1=$ ada kepemilikan asing & 96 \\
& $0=$ tidak ada kepemilikan asing & 4 \\
Tipe Industri & $1=$ industri high profile & 93 \\
& $0=$ industri low profile & 7 \\
\hline
\end{tabular}

Sumber: Data diolah, 2021

Dari hasil analisis Tabel 3 dapat diketahui bahwa untuk variabel kepemilikan asing yang diukur menggunakan menggunakan variabel dummy, yaitu skor $1=$ bila ada kepemilikan asing dan skor $0=$ bila tidak ada kepemilikan asing. Berikut persentase kepemilikan asing dalam penelitian ini dijelaskan dalam Gambar 2.

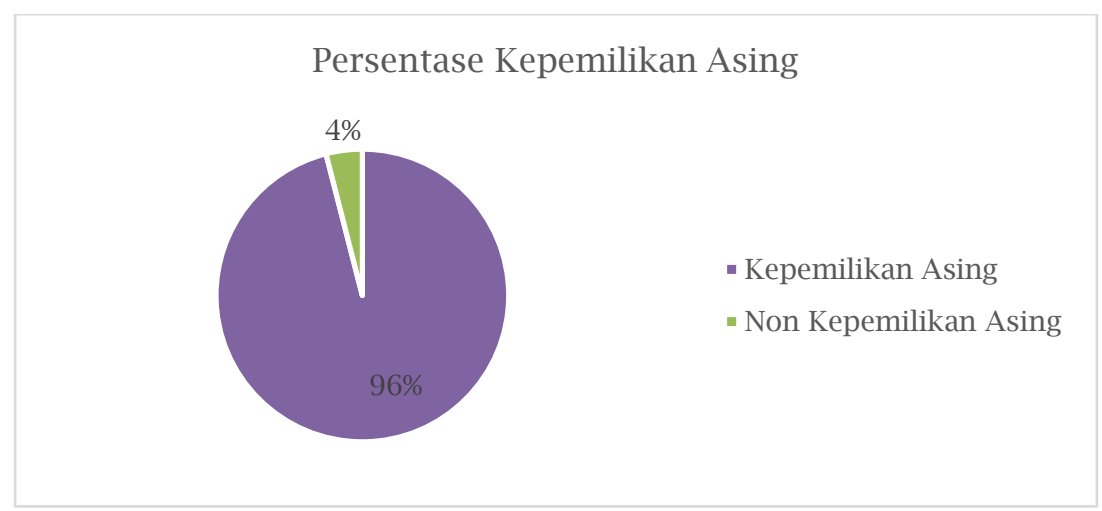

Gambar 2. Diagram Variabel Kepemilikan Asing

Dari Gambar 2 dapat diketahui bahwa persentase perusahaan yang memiliki kepemilikan asing adalah sebesar 96\% dan perusahaan non kepemilikan asing yaitu sebesar 4\%. Hal ini menujukkan bahwa dari total sampel 96 perusahaan yang digunakan dalam penelitian ini, ada 92 perusahaan yang memiliki kepemilikan asing dan ada 4 perusahaaan yang tidak memiliki kepemilikan asing.

Tipe industri diukur menggunakan menggunakan variabel dummy, yaitu skor 1 untuk industri high profile dan skor 0 untuk industri low profile. Berikut persentase tipe industri dalam penelitian ini dijelaskan dalam Gambar 3.

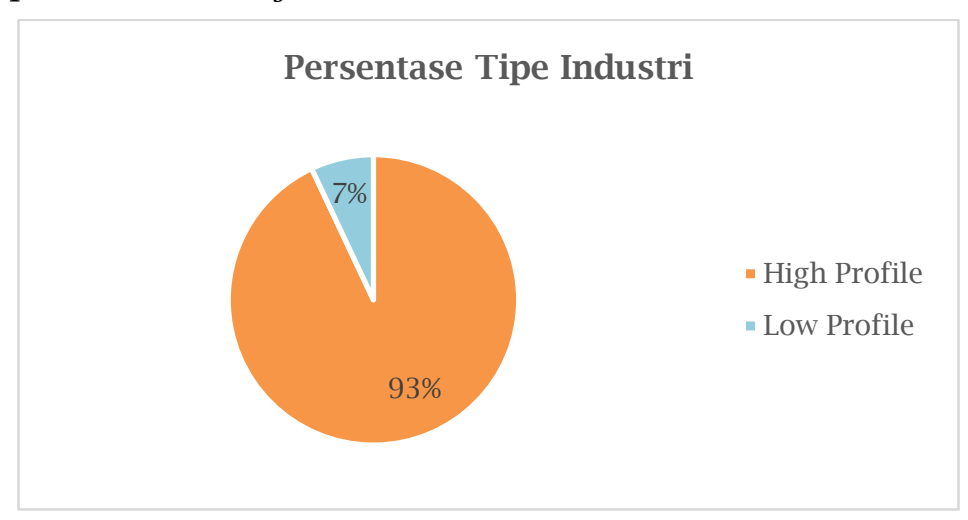

Gambar 3. Diagram Variabel Tipe Industri

Dari Gambar 3 dapat diketahui bahwa persentase perusahaan yang masuk dalam tipe industri high profile adalah sebesar 93\% dan perusahaan tipe low profile yaitu sebesar 7\%. Hal ini menujukkan bahwa dari total sampel 96 perusahaan yang digunakan dalam penelitian ini, ada 89 perusahaan yang bertipe industri high profile dan ada 7 perusahaaan yang bertipe industri low profile. 
Nanda Amelia Jauhari, Fajar Satriya Segarawasesa | Determinan Pengungkapan Corporate Social Responsibility (Studi Empiris pada Perusahaan Manufaktur yang Terdaftar di Bursa Efek Indonesia)

Sementara hasil analisis statistik deskriptif variabel dependen dijelaskan dalam Tabel 4.

Tabel 4. Hasil Analisis Statistik Deskriptif Varibel Dependen

\begin{tabular}{cccccc}
\hline & $\mathrm{N}$ & Minimun & Maximum & Mean & Std. Deviation \\
\hline CSR & 288 & 0,1 & 69 & 0,1539 & 0,10764 \\
\hline \multicolumn{6}{c}{ Sumber: Data diolah SPSS, 2021} \\
\end{tabular}

Dari hasil analisis pada Tabel 4 dapat diketahui bahwa variabel pengungkapan CSR yang diukur menggunakan indeks GRI 4 memiliki nilai rata-rata sebesar 0,1539 atau 15,39\% dengan nilai standar deviasi sebesar 0,10764. Hasil penelitian ini menunjukkan bahwa nilai pengungkapan CSR di Indonesia belum konsisten untuk dikatakan bernilai tinggi. Hal ini dikarenakan hasil penelitian untuk variabel pengungkapan CSR selalu bervariasi setiap tahunnya yang dapat dilihat dari hasil penelitian-penelitian sebelumnya antara lain yaitu penelitian yang dilakukan oleh Istifaroh dan Subardjo (2017) adalah sebesar 29\%, Wati (2018) sebesar 16\%, Rindiyawati dan Arifin (2019) sebesar 55\%.

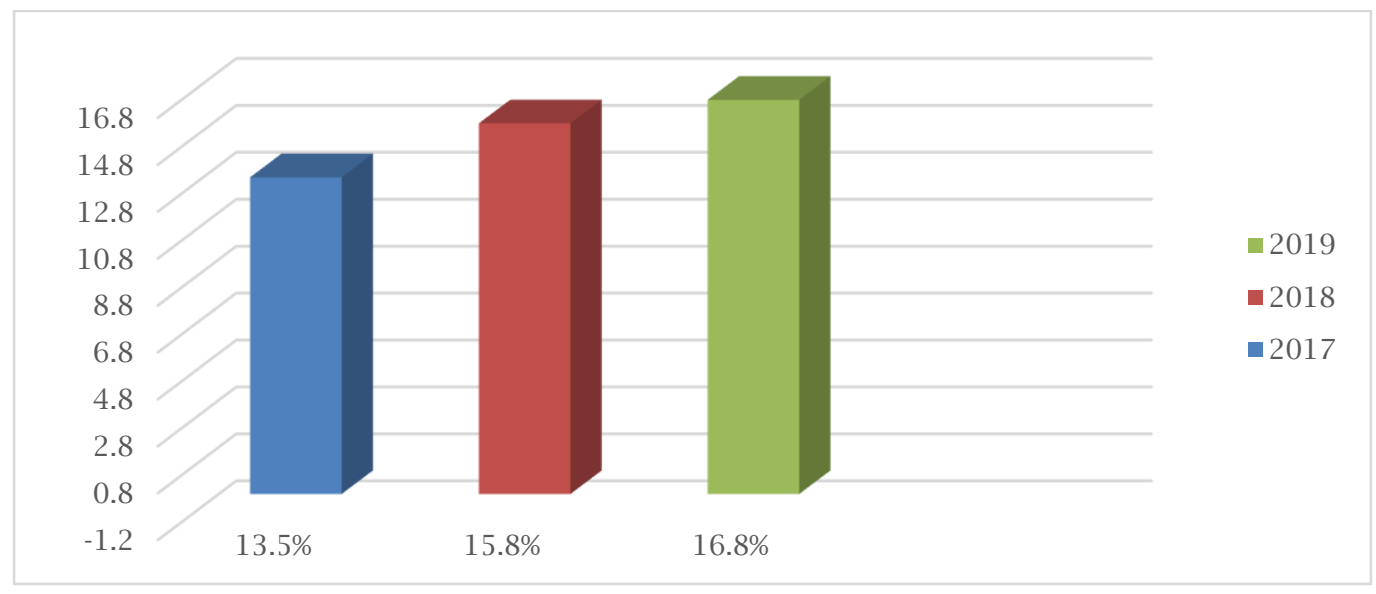

Gambar 4. Grafik Pengungkapan CSR tahun 2017-2019

Dari Gambar 4 dapat diketahui bahwa nilai pengungkapan CSR terendah berada pada tahun 2017 yaitu sebesar 13,5\% sedangkan pengungkapan tertinggi berada pada tahun 2019 sebesar 16,8\%. Hal ini menunjukkan bahwa ada peningkatan nilai CSR setiap tahunnya pada perusahaan manufaktur di Indonesia meskipun nilai peningkatan tersebut masih terbilang rendah. Peningkatan nilai pengungkapan CSR ini menunjukkan bahwa perusahaan telah menyadari pentingnya melakukan pengungkapan tanggung jawab sosial perusahaan demi kepentingan masyarakat maupun lingkungan sekitar.

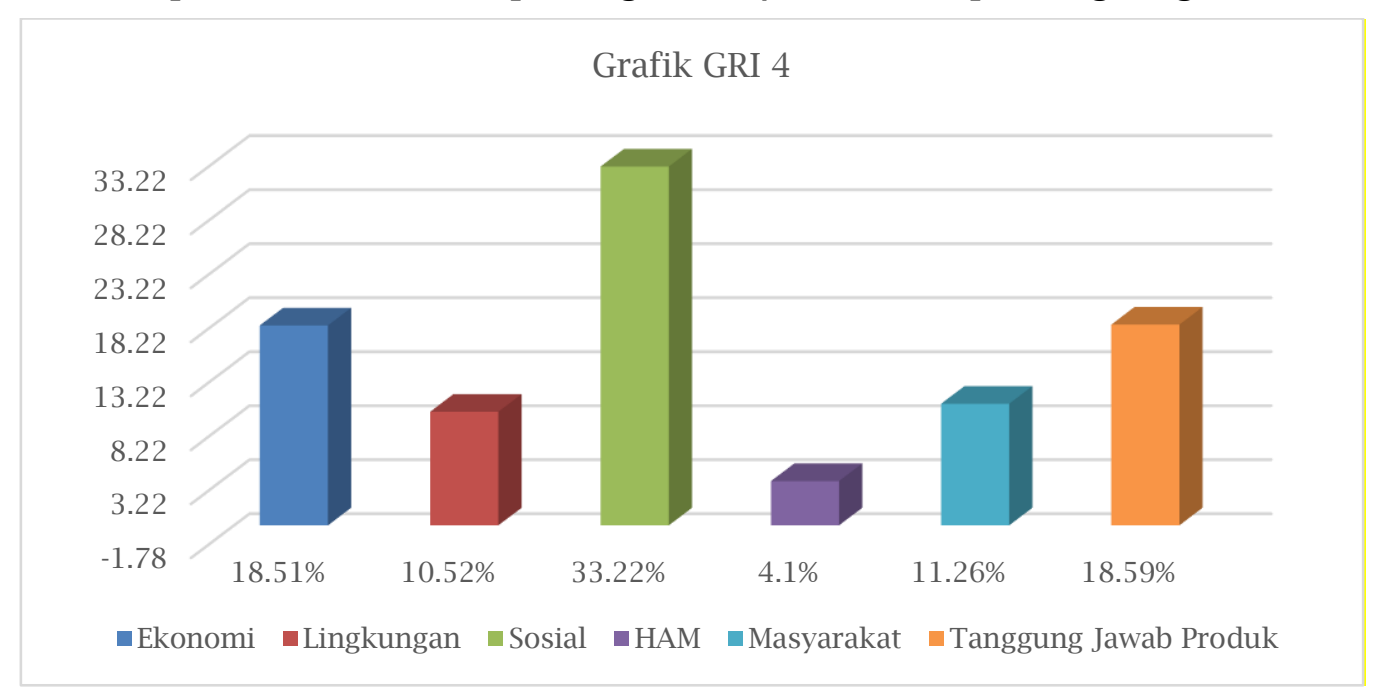

Gambar 5. Grafik Indeks Pengungkapan GRI 4 
Nanda Amelia Jauhari, Fajar Satriya Segarawasesa | Determinan Pengungkapan Corporate Social Responsibility (Studi Empiris pada Perusahaan Manufaktur yang Terdaftar di Bursa Efek Indonesia)

Dari Gambar 5 dapat diketahui bahwa tingkat pengungkapan CSR pada perusahaan manufaktur selama tahun 2017-2019 diperoleh bahwa tingkat pengungkapan terbesar berada pada kategori "sosial" dengan jumlah persentase sebesar 33,22\%. Kategori ini berisi informasi perusahaan tentang aspek kepegawaian, aspek hubungan industrial, aspek kesehatan dan keselamatan kerja, aspek pelatihan dan pendidikan, aspek keberagaman dan kesetaraan peluang, aspek kesetaraan remunerasi perempuan dan laki-laki, aspek asesmen pemasok atas praktik ketenagakerjaan, dan aspek mekanisme pengaduan masalah ketenagakerjaan. Tingginya pengungkapan ketegori sosial ini kemungkinan disebabkan karena perusahaan menyadari bahwa sumber daya manusia merupakan salah satu elemen pendukung pengembangan perusahaan, oleh karena itu perusahaan selalu memastikan bahwa kualitas dan kompetensi sumber daya manusianya meningkat setiap tahunnya seiring dengan perkembangan teknologi dan informasi serta terobosan-terobosan yang harus dilakukan, dalam rangka pengembangan sosial yang inovatif dan berorientasi penuh terhadap produk berkualitas serta ramah lingkungan.

Tingkat pengungkapan tertinggi kedua berada pada kategori "tanggung jawab produk" dengan jumlah persentase sebesar 18,59\%. Kategori ini berisi informasi perusahaan tentang aspek kesehatan dan keselamatan pelanggan, aspek pelabelan produk dan jasa, aspek komunikasi pemasaran, aspek privasi pelanggan, dan aspek kepatuhan. Tingginya pengungkapan ketegori tanggung jawab produk ini kemungkinan disebabkan karena sebagai perusahaan yang menghasilkan sebuah produk, maka prioritas utama perusahaan manufaktur merupakan keamanan produk. Selain itu pengungkapan mengenai tanggung jawab produk ini juga sebagai komitmen terhadap konsumen bahwa perusahaan hanya mempersembahkan produk yang berkualitas tinggi.

Tingkat pengungkapan tertinggi ketiga berada pada kategori "ekonomi" dengan jumlah persentase sebesar 18,51\%. Kategori ini berisi informasi perusahaan tentang aspek kinerja ekonomi, aspek keberadaan di pasar, aspek dampak ekonomi langsung, dan aspek praktik pengadaan. Tingginya pengungkapan ketegori ekonomi ini kemungkinan disebabkan karena informasi ekonomi dapat memberikan dampak terhadap kestabilan seluruh kegiatan operasi perusahaan. Pemangku kepentingan, khususnya investor, akan memantau kinerja ekonomi perusahaan. Oleh karena itu informasi ekonomi menjadi salah satu aspek yang perlu diungkapkan dalam laporan tahunan.

\section{Uji Asumsi Klasik}

Uji asumsi klasik dalam penelitian ini dilakukan sebagai syarat sebelum dilakukannya uji regresi berganda, sehingga hasil penelitian terhindar dari hasil yang bias. Uji asumsi klasik pada penelitian ini dilakukan dengan menggunakan uji normalitas, uji multikoleniaritas, uji autokorelasi dan uji heterosteskedasitas. Uji normalitas Kolmogorov-Smirnov dalam penelitian ini menunjukkan nilai signifikansi Asymp. Sig (2-tailed) yaitu sebesar 0,083 atau lebih besar dari 0,05 sehingga dapat disimpulkan bahwa data residual berdistribusi normal dan model regresi telah memenuhi asumsi normalitas. Uji multikolonieritas menunjukkan bahwa seluruh variabel memiliki nilai tolerance lebih besar dari 0,1 dan nilai VIF lebih kecil dari 10, sehingga dapat disimpulkan bahwa tidak adanya korelasi antar variabel independen, atau dapat dikatakan bahwa tidak terjadi multikolinearitas. Uji autokorelasi yang diuji menggunakan Durbin-Watson menunjukkan bahwa nilai DW adalah 1,002, sehingga dapat disimpulkan bahwa tidak terjadi autokorelasi karena nilai DW yaitu 1,002 diantara -2 dan +2 . Uji heterokedastisitas menunjukkan bahwa seluruh variabel memiliki nilai signifikansi $>0,05$, sehingga dapat disimpulkan bahwa variabel yang diuji tidak mengandung heteroskedastisitas. 
Nanda Amelia Jauhari, Fajar Satriya Segarawasesa | Determinan Pengungkapan Corporate Social Responsibility (Studi Empiris pada Perusahaan Manufaktur yang Terdaftar di Bursa Efek Indonesia)

\section{Analisis Regresi Linier Berganda}

Tabel 5. Hasil Analisis Regresi Linier Berganda

\begin{tabular}{lcccc}
\hline \multicolumn{1}{c}{ Variabel } & Prediksi & $\begin{array}{c}\text { Koefisien } \\
\text { Regresi }\end{array}$ & Sig & Kesimpulan \\
\hline Konstanta & & $-1,907$ & 0,001 & Terdukung \\
Umur Perusahaan & + & 0,968 & 0,007 & Tidak Terdukung \\
Kepemilikan Asing & + & 0,024 & 0,417 & Terdukung \\
Dewan Komisaris & + & 0,243 & 0,000 & Tidak Terdukung \\
Komite Audit & + & 0,157 & 0,295 & Terdukung \\
Tipe Industri & + & 0,054 & 0,012 & \\
Model Summary: & & & & \\
Adjusted R Square & $: 0,148$ & & \\
Standar Error Estimasi : 0,0902073105 & \\
Regresion Model & $: 0,000$ & & \\
\hline
\end{tabular}

Sumber: Data diolah SPSS, 2021

Berdasarkan Tabel 5, persamaan regresi berganda dirumuskan sebagai berikut.

$\mathrm{Y}=-1,907+0,968 \mathrm{UP}+0,243 \mathrm{DEKOM}+0,054 \mathrm{TI}+\varepsilon$

Dari hasil analisis pada Tabel 5 dapat diketahui bahwa:

1. Nilai konstanta adalah sebesar $-1,907$, maka dapat dinyatakan bahwa apabila seluruh variabel independen bernilai sama dengan 0, maka besarnya nilai CSR adalah sebesar -1,907. Hal ini mengindikasikan bahwa dalam penelitian ini ketika variabel independen bernilai 0, maka CSR mengalami penurunan sebesar -1,907.

2. Nilai koefisien variabel umur perusahaan (UP) adalah sebesar 0,968. Hal ini menunjukkan bahwa setiap peningkatan umur perusahaan sebesar satu satuan akan diikuti dengan peningkatan tingkat pengungkapan CSR sebesar 0,968 sebaliknya setiap penurunan umur perusahaan sebesar $1 \%$ akan menurunkan pengungkapan CSR sebesar 0,968 dengan asumsi variabel lainnya konstan.

3. Nilai koefisien variabel dewan komisaris (DEKOM) adalah sebesar 0,243. Hal ini menunjukkan bahwa setiap peningkatan dewan komisaris sebesar satu satuan akan diikuti dengan peningkatan tingkat pengungkapan CSR sebesar 0,243 sebaliknya setiap penurunan dewan komisaris sebesar 1\% akan menurunkan pengungkapan CSR sebesar 0,243 dengan asumsi variabel lainnya konstan.

4. Nilai koefisien variabel tipe industri (TI) adalah sebesar 0,054. Hal ini menunjukkan bahwa setiap peningkatan tipe industri sebesar satu satuan akan diikuti dengan peningkatan tingkat pengungkapan CSR sebesar 0,157 sebaliknya setiap penurunan tipe industri sebesar 1\% akan menurunkan pengungkapan CSR sebesar 0,054 dengan asumsi variabel lainnya konstan.

\section{Pembahasan}

Berdasarkan hasil uji regresi linier berganda, Tabel 5 menunjukkan bahwa umur perusahaan berpengaruh positif terhadap pengungkapan CSR dengan nilai signifikansi $0,007<0,05$ dan nilai koefisien regresi 0,968, maka dapat disimpulkan bahwa $\mathrm{H1}$ terdukung. Berdasarkan teori legitimasi, legitimasi organisasi merupakan suatu hal yang sangat dibutuhkan oleh perusahaan dari masyarakat itu sendiri. Perusahaan yang memiliki umur yang panjang merupakan perusahaan yang dapat bertahan cukup lama dalam kehidupan bisnisnya, keberlangsungan hidup perusahaan ini terus berlanjut karena adanya sebuah pengakuan dari masyarakat yaitu legitimasi (Ciriyani \& Putra, 2016). Maka sebagai bentuk dari tanggung jawab atas legitimasi yang telah diberikan tersebut, perusahaan akan semakin banyak mengungkapkan informasi lingkungannya pada laporan tahunan yang mereka terbitkan. Dengan demikian diharapkan masyarakat dapat terus menerima keberadaan perusahaan dan memberikan legitimasi mereka, sehingga keberlangsungan perusahaan dapat terus berlanjut.

Kepemilikan asing tidak berpengaruh terhadap pengungkapan CSR. Hal tersebut dibuktikan dengan hasil uji regresi linier berganda pada Tabel 5 dengan nilai signifikansi 
Nanda Amelia Jauhari, Fajar Satriya Segarawasesa | Determinan Pengungkapan Corporate Social Responsibility (Studi Empiris pada Perusahaan Manufaktur yang Terdaftar di Bursa Efek Indonesia)

0,417 > 0,05 artinya H2 tidak terdukung. Tidak terdukungnya hipotesis ini menunjukkan bahwa ada atau tidaknya kepemilikan asing dalam suatu perusahaan tidak mempengaruhi luas pengungkapan CSR. Hal ini disebabkan karena para investor asing murni hanya ingin melakukan investasi di perusahaan Indonesia sehingga dianggap belum mempunyai kesadaran terhadap aspek lingkungan dan sosial di sekitar perusahaan sebagai isu penting yang harus diangkat dalam laporan tahunan perusahaan. Maulidra (2015) dalam Rohmah (2015) juga mengungkapkan alasan lain kepemilikan asing tidak berpengaruh terhadap pengungkapan CSR yaitu karena ratarata perusahaan sampel lebih didominasi oleh perusahaan yang tidak memiliki kepemilikan saham asing yang besar tetapi pengungkapan CSR sudah cukup efektif terlaksana sehingga tidak terdapat hubungan yang signifikan antara jumlah persentase kepemilikan saham asing terhadap luas atau tidaknya pengungkapan.

Dewan komisaris berpengaruh positif terhadap pengungkapan CSR. Hal tersebut dibuktikan dengan hasil uji regresi linier berganda pada Tabel 5 dengan nilai signfikansi $0,000<0,05$ dan nilai koefisien regresi 0,243, maka dapat disimpulkan bahwa H3 terdukung. Dalam teori agensi, dewan komisaris dianggap sebagai mekanisme pengendalian intern tertinggi yang bertanggung jawab untuk memonitor tindakan manajemen puncak yang berarti dewan komisaris memiliki kekuasaan yang luas dalam mengawasi dan mengendalikan manajemen perusahaan agar pengelolaan perusahaan semakin efektif, sehingga kekuasaan ini diharapkan dapat digunakan untuk memberikan pengaruh yang besar dalam pelaksanaan CSR. Semakin besar jumlah anggota dewan komisasris, maka semakin mudah untuk mengendalikan direksi dan pengawasan yang dilakukan akan semakin efektif sehingga dapat meminimalkan kemungkinan informasi yang ditutupi termasuk informasi mengenai pengungkapan tanggung jawab sosial perusahaan.

Komite audit tidak berpengaruh terhadap pengungkapan CSR. Hal tersebut dibuktikan dengan hasil uji regresi linier berganda pada Tabel 5 dengan nilai signifikansi 0,295 > 0,05 artinya H4 tidak terdukung. Tidak terdukungnya hipotesis ini dikarenakan dalam POJK No. 55/POJK.04/2015 pasal 10 yang memuat tugas dan tanggung jawab komite audit, komite audit secara garis besar merupakan pihak yang melakukan pengawasan internal terhadap perusahaan, bukan sebagai pihak yang memiliki wewenang untuk mendorong pengungkapan CSR perusahaan. Komite audit sendiri secara garis besar bertanggung jawab atas tiga bidang yaitu laporan keuangan, tata kelola, dan pengawasan perusahaan. Variabel komite audit tidak berpengaruh terhadap pengungkapan CSR dikarenakan pembentukan komite audit masih sebatas untuk memenuhi regulasi yang diatur oleh pemerintah, komite audit belum efektif dalam melaksanakan tanggung jawab atas tiga bidang tersebut karena komite audit cenderung hanya melakukan fungsi pengawasan terhadap kinerja perusahaan yang berkaitan dengan review pengendalian intern dan kualitas laporan keuangan daripada laporan lain yang bersifat value added seperti laporan berkelanjutan yang berisi pengungkapan CSR perusahaan.

Tipe industri berpengaruh positif terhadap pengungkapan CSR. Hal tersebut dibuktikan dengan hasil uji regresi linier berganda pada Tabel 5 dengan nilai signfikansi $0,012<0,05$ dan nilai koefisien regresi 0,054, maka dapat disimpulkan bahwa H5 terdukung. Dalam teori legitimasi yang melandasi adanya kontrak sosial antara perusahaan dengan masyarakat, haruslah berdampak saling menguntungkan antara kedua belah pihak, salah satunya dengan melalui kegiatan CSR (Widiastuti dkk., 2018). Aktivitas operasional perusahaan yang membawa dampak terhadap lingkungan dan sosial masyarakat perlu melakukan kegiatan CSR sebagai upaya meminimalkan konflik serta untuk mendapatkan legitimasi dari masyarakat.

\section{SIMPULAN, KETERBATASAN, DAN SARAN}

Hasil penelitian menunjukkan bahwa umur perusahaan, dewan komisaris dan tipe industri berpengaruh positif terhadap pengungkapan CSR, sedangkan kepemilikan asing 
Nanda Amelia Jauhari, Fajar Satriya Segarawasesa | Determinan Pengungkapan Corporate Social Responsibility (Studi Empiris pada Perusahaan Manufaktur yang Terdaftar di Bursa Efek Indonesia)

dan komite audit tidak berpengaruh terhadap pengungkapan CSR. Keterbatasan penelitian ini antara lain penelitian ini hanya dilakukan pada perusahaan sektor manufaktur sehingga hasil penelitian tidak dapat digeneralisasikan secara luas, Periode penelitian masih terbilang pendek yaitu selama tiga tahun (2017-2019 sehingga hasilnya kurang mencerminkan keadaan dalam jangka panjang dan terdapat unsur subjektivitas dalam menentukan indeks pengungkapan CSR. Karena laporan tahunan tidak disajikan secara eksplisit sehingga masih memerlukan interpretasi penilaian. Saran untuk penelitian selanjutnya penelitian selanjutnya dapat menggunakan cara pengungkapan CSR yang lainnya, sehingga bisa terjadi keberagaman penelitian seperti total biaya CSR perusahaan, penelitian selanjutnya dapat menambah variabel independen yang diduga mampu menjelaskan secara maksimal variasi terhadap variabel dependen yang terkait dengan pengungkapan CSR, seperti agresivitas pajak, growth opportunity dan lain-lain. Kemudian dapat memperluas unit analisis penelitian tidak hanya perusahaan di Indonesia saja, tetapi juga di negara berkembang lainnya untuk membandingkan pengungkapan CSR di Indonesia dengan negara berkembang lainnya.

\section{DAFTAR PUSTAKA}

Adawiyah, I. R. (2013). Pengaruh Tipe Industri, Ukuran Perusahaan, Profitabilitas dan Leverage Terhadap Pengungkapan Corporate Social Responsibility. Skripsi UIN Syarif Hidayatullah Jakarta.

Arfansyah. (2018). Pengaruh Kepemilikan Asing, Solvabilitas, Likuiditas dan Ukuran dewan Komisaris Terhadap Pengungkapan Corporate Social Responsibility. Jurnal Online Mahasiswa Fakultas Ekonomi Universitas Riau, 1(1), 1-15. https://jom.unri.ac.id/index.php/JOMFEKON/article/view/20997/20320

Arjanggie, A. R., \& Zulaikha, Z. (2015). Pengaruh Profitabilitas dan Umur Perusahaan terhadap Pengungkapan Tanggung Jawab Sosial Perusahaan. Diponegoro Journal of Accounting, $\quad 4(3), \quad 496-506$. https://ejournal3.undip.ac.id/index.php/accounting/article/view/17022

Budiman, N. A. (2015). Faktor-Faktor Yang Mempengaruhi Pengungkapan Tanggung Jawab Sosial Perusahaan. Jurnal Riset Akuntansi Mercu Buana, 1(1), 14-34. https://doi.org/10.26486/jramb.v1i1.9

Ciriyani, N., \& Putra, I. (2016). Pengaruh Ukuran Perusahaan, Profitabilitas, Dan Umur Perusahaan Pada Pengungkapan Informasi Lingkungan. E-Jurnal Akuntansi, 17(3), 2091-2119. https://ojs.unud.ac.id/index.php/Akuntansi/article/view/22400

Diyanti, F. (2013). Mekanisme Good Corporate Governance dan Mandatory Disclosure: Studi Empiris pada Perusahaan Manufaktur yang Terdaftar di Bursa Efek Indonesia. AKUNTABEL: Jurnal Akuntansi dan Keuangan, 10(2), 37-48. http://dx.doi.org/10.29264/jakt.v10i2.60

Ismaningtyas, B., Suryono, B., \& Wahidahwati, W. (2020). Faktor-Faktor Yang Mempengaruhi Pengungkapan Corporate Social Responsibility. Wahana: Jurnal Ekonomi, Manajemen dan Akuntansi, 23(1), 1-23. https://doi.org/10.35591/wahana.v23i1.183

Istifaroh, A., \& Subardjo, A. (2017). Faktor-Faktor yang Mempengaruhi Pengungkapan Corporate Social Responsibility. Jurnal Ilmu dan Riset Akuntansi, 6(6), 1-19. http://jurnalmahasiswa.stiesia.ac.id/index.php/jira/article/view/486/496

Jensen, M. C., \& Meckling, W. H. (1976). Theory of the Firm: Managerial Behavior, Agency Cost and Ownerhip Structure. Journal of Financial Economics, 3(4), 305-360. https://doi.org/10.1016/0304-405X(76)90026-X

Komite Nasional Kebijakan Governance (KNKG). (2006). Pedoman Umum Good Corporate Governance Indonesia. 1-27.

Mudjiyanti, R., \& Maulani, S. S. (2017). Pengaruh Likuiditas dan Profitabilitas Terhadap Pengungkapan Corporate Social Responsibility pada Perusahaan Terdaftar di Bursa Efek Indonesia. Jurnal Akuntansi dan Sistem Teknologi Informasi, 13(3), 342-346. http://ejurnal.unisri.ac.id/index.php/Akuntansi/article/download/1846/1636

Natalylova, K. (2013). Pengaruh corporate governance terhadap corporate social 
Nanda Amelia Jauhari, Fajar Satriya Segarawasesa | Determinan Pengungkapan Corporate Social Responsibility (Studi Empiris pada Perusahaan Manufaktur yang Terdaftar di Bursa Efek Indonesia)

responsibility dan kinerja perusahaan yang mendapatkan indonesia suistainabilty reporting awards. Media Bisnis, 162-182.

Nindiasari, A. D. (2021). Good corporate governance practices and voluntary disclosure in companies listed in the Indonesia Sharia Stock Index (ISSI). Asian Journal of Islamic Management $\quad$ (AJIM), $\quad 3(1), \quad 45-55$. https://doi.org/10.20885/ajim.vol3.iss1.art5

Nurfadilah, W., \& Sagara, Y. (2015). Pengaruh Good Corporate Governance, Karakteristik Perusahaan dan Regulasi Pemerintah Terhadap Pengungkapan Corporate Social Responsibility. Akuntabilitas, 8(1), 78-89. https://doi.org/10.15408/akt.v8i1.2763

Nurhayati, R., Brown, A., \& Tower, G. (2006). A Developing Country's Natural Environment Disclosure Index. Accounting and Finance Association of Australia and New Zealand. https://www.unisa.edu.au/siteassets/episerver-6files/global/business/centres/cags/docs/apcea/apcea_2006_123_nurhayati_brow n_tower.pdf

Oktariani, W. (2013). Pengaruh Kepemilikan Publik, Ukuran Dewan Komisaris, Profitabilitas dan Umur Perusahaan Terhadap Pengungkapan Tanggung Jawab Sosial Perusahaan. Jurnal Ilmiah Wahana Akuntansi, 8(2), 100-117. http://journal.unj.ac.id/unj/index.php/wahana-akuntansi/article/view/857/765

POJK No. 55/POJK.04/2015. (2015). Peraturan Otoritas Jasa Keuangan Nomor 55 /POJK.04/2015 tentang Pembentukan dan Pedoman Pelaksanaan Kerja Komite Audit.

POJK Nomor 33/POJK.04/2014. (2014). Peraturan Otoritas Jasa Keuangan Nomor 33 /POJK.04/2014 tentang Direksi dan Dewan Komisaris Emiten Atau Perusahaan Publik.

Pratiwi, L., \& Ismawati, K. (2019). Analisis Pengaruh Tipe Industri, Ukuran Perusahaan, Leverage dan Profitabilitas Terhadap Pengungkapan Corporate Social Responsibility (CSR) pada Perusahaan Manufaktur di Bursa Efek Indonesia Tahun 2012-2014. Surakarta Accounting Review, 1(1), 16-25. http://www.unsa.ac.id/ejournal/index.php/sarev/article/download/241/194

Purnaningsih, D. (2018). Pengaruh Corporate Social Responsibility Terhadap Kinerja Keuangan Pada Perusahaan Manufaktur yang Terdaftar di Bursa Efek Indonesia (BEI). Skripsi Universitas Islam Indonesia.

Rindiyawati, A., \& Arifin, J. (2019). Determinan Pengungkapan Corporate Social Responsibility Pada Industri Perbankan. Jurnal Akuntansi dan Bisnis, 19(1), 1-12. https://doi.org/10.20961/jab.v19i1.244

Rohmah, D. (2015). Faktor-Faktor yang Mempengaruhi Pengungkapan Corporate Social Responsibility di dalam Laporan Sustainability (Studi Empiris pada Perusahaan yang Listing di Bursa Efek Indonesia Tahun 2010-2013). Esensi: Jurnal Bisnis dan Manajemen, 5(2), 243-262. https://doi.org/10.15408/ess.v5i2.2347

Said, R., Zainuddin, Y., \& Haron, H. (2009). The relationship between corporate social responsibility disclosure and corporate governance characteristics in Malaysian public listed companies. Social Responsibility Journal, 5(2), 212-226. https://doi.org/10.1108/17471110910964496

Sanditoso, L., \& Chandra, E. (2012). Pengaruh Profitabilitas, Ukuran Perusahaan, Leverage, Umur Perusahaan, dan Dewan Komisaris Independen dalam Pengungkapan Corporate Social Responsibility. Jurnal Bisnis dan Akuntansi, 14(1), 17-30. https://doi.org/10.34208/jba.v14i1.102.

Saputri, D. (2019). Analisis Faktor-Faktor yang Mempengaruhi Pengungkapan Corporate Social Responsibility (CSR) (Studi Empiris Pada Perusahaan Manufaktur Yang Terdaftar Di Bursa Efek Indonesia Tahun 2013-2017). Skripsi Universitas Muhammadiyah Magelang.

Segarawasesa, F. S. (2021). Analysis of factors affecting sharia compliance levels in sharia banks in Indonesia. Asian Journal of Islamic Management (AJIM), 3(1), 56-66. https://doi.org/10.20885/ajim.vol3.iss1.art6

Sembiring, E. R. (2006). Karakteristik Perusahaan dan Pengungkapan Tanggung Jawab Sosial: Study Empiris pada Perusahaan yang Tercatat di Bursa Efek Jakarta. Jurnal Maksi, $6(1)$, 69-85. 
Nanda Amelia Jauhari, Fajar Satriya Segarawasesa | Determinan Pengungkapan Corporate Social Responsibility (Studi Empiris pada Perusahaan Manufaktur yang Terdaftar di Bursa Efek Indonesia)

http://eprints.undip.ac.id/35124/1/JMAKSI_Jan_2006_05_Edy_Rismanda_Sembiri ng.pdf

Soewardjono. (2015). Teori Akuntansi: Perekayasaan dan Pelaporan Keuangan Edisi Ketiga. Yogyakarta: BPFE.

Sudana, I. M., \& Arlindania, P. A. (2011). Corporate Governance dan Pengungkapan Corporate Social Responsibility pada Perusahaan Go-Public di Bursa Efek Indonesia. Jurnal Manajemen Teori dan Terapan/ Journal of Theory \& Applied Management, 4(1), 37-49. https://doi.org/10.20473/jmtt.v4i1.2411

Sukandar, P. P., \& Rahardja, R. (2014). Pengaruh Ukuran Dewan Direksi dan Dewan Komisaris serta Ukuran Perusahaan Terhadap Kinerja Keuangan Perusahaan (Studi Empiris pada Perusahaan Manufaktur Sektor Consumer Good yang Terdaftar di BEI Tahun 2010-2012). Diponegoro Journal of Accounting, 3(3), 689-695. https://ejournal3.undip.ac.id/index.php/accounting/article/download/6211/5997

Sukasih, A., \& Sugiyanto, E. (2017). Pengaruh Struktur Good Corporate Governance dan Kinerja Lingkungan Terhadap Pengungkapan Corporate Social Responsibility (Studi Pada Perusahaan Manufaktur di Bursa Efek Indonesia Periode 2011-2015). Riset Akuntansi dan Keuangan Indonesia, 2(2), 121-131. https://doi.org/10.23917/reaksi.v2i2.4894

Sumilat, H., \& Destriana, N. (2017). Faktor-Faktor Yang Mempengaruhi Pengungkapan Corporate Social Responsibility (CSR) Dalam Laporan. Jurnal Bisnis dan Akuntansi, 19(1a-2), 129-140. https://doi.org/10.34208/jba.v19i1a-2.307

Suryono, H., \& Prastiwi, A. (2011). Pengaruh Karakteristik Perusahaan dan Corporate Governance (CG) Terhadap Praktik Pengungkapan Sustainability Report (SR) (Studi Pada Perusahaan - Perusahaan yang Listed (Go-Public) di Bursa Efek Indonesia (BEI) Periode 2007-2009). Simposium Nasional Akuntansi XIV Aceh 2011.

Taduga, F. K., \& Noval, M. (2019). Analisis Kepemilikan Asing Dan Nilai Perusahaan. Jurnal Ilmu Manajemen Universitas Tadulako, 5(3), 298-310. https://doi.org/10.22487/jimut.v5i3.161

Undang-Undang Republik Indonesia Nomor 25 Tahun 2007 tentang Penanaman Modal.

Undang-Undang Republik Indonesia Nomor 40 Tahun 2007 tentang Perseroan Terbatas.

Vivian, V., Wijaya, Y., Charlie, F., Winnie, W., Devi, D., \& Rahmi, N. U. (2020). Pengaruh Profitabilitas, Leverage, Ukuran Perusahaan, Umur Perusahaan, dan Dewan Komisaris Independen Terhadap Corporate Social Responsibility pada Perusahaan Pertambangan yang Terdaftar di Bursa Efek Indonesia pada Periode 2014-2018. Jurnal Ilmiah MEA (Manajemen, Ekonomi, \& Akuntansi), 4(3), 257-274. https://doi.org/10.31955/mea.vol4.iss3.pp257-274

Wahyu, I., \& Apriwenni, P. (2012). Pengaruh Mekanisme Corporate Governance, Ukuran Perusahaan, dan Profitabilitas Terhadap Luas Pengungkapan Corporate Social Responsibility (CSR) pada Perusahaan Manufaktur yang Terdaftar di Bursa Efek Indonesia (BEI) Periode 2007-2009. Auditing 1(1), 43-59.

Wati, L. N. (2018). Faktor-Faktor Yang Mempengaruhi Pengungkapan Corporate Social Responsibility dengan GRI 3. Jurnal Ecodemica 2(2), 240-252. https://doi.org/10.31294/jeco.v2i2.4457

Widiastuti, H., Utami, E. R., \& Handoko, R. (2018). Pengaruh Ukuran Perusahaan, Tipe Industri, Growth dan Media Exposure Terhadap Pengungkapan Tanggung Jawab Sosial Perusahaan (Studi Empiris pada Perusahaan yang Terdaftar di Bursa Efek Indonesia Tahun 2014-2015). Riset Akuntansi dan Keuangan Indonesia, 3(2), 107117. https://doi.org/10.23917/reaksi.v3i2.6745 